\title{
SYNTHESIS OF COMPLEX OF L-GLUTAMIC ACID WITH Mn (II) AND ITS INHIBITION ACTIVITY AGAINST PATHOGENS.
}

\author{
M. M. Kodape ${ }^{1}$, N. D. Gawhale ${ }^{2}$ P. N. Chunarkar ${ }^{3}$, M. M. Mahajan 4 , \\ R. N. Tong 5 \\ 1,4,5Department of Chemistry, Sant Gadge Baba Amaravati University, \\ Amaravati-444 602 (M.S.) India. \\ ${ }^{2}$ Department of Chemistry, G.S. Tompe College, Chandur Bazar, Dist.- \\ Amravati-444704 (M.S.) India. \\ ${ }^{3}$ Department of Bioinformatics, Rajiv Gandhi Institute of Information \\ Technology and Biotechnology, Bharati Vidyapeeth Deemed University \\ Pune-46, (M.S.) India. \\ Email of corresponding author: : mmkodape@gmail.com
}

\begin{abstract}
:
Coordination compound of L-Glutamic acid with manganese was synthesized and characterized using Infrared spectroscopy, Nuclear magnetic resonance and CHNS analysis. The ligand L-Glutamic Acid coordinated to the $\mathrm{Mn}$ using $\mathrm{N}$ and $\mathrm{O}$ donor atoms. The biological activity of the synthesized complex was investigated. The complex was tested against different pathogens, zones of inhibition was observed against Candida albicans with minimum inhibition concentration $(\mathrm{MIC}=10 \mu \mathrm{l})$ for the synthesized complex.
\end{abstract}

Keywords: L-Glutamic acid, Manganese, Coordination complex, Pathogens.

\section{Introduction:}

The metal ion complexes of many amino acids have been investigated [16]. L-Glutamic acid (Glu) plays a vital role in various biochemical processes at the molecular levels. The carboxylate anions and salts of glutamic acid are known as glutamates. In neuroscience, glutamate is an important neurotransmitter that plays a key role in long-term 
potentiation and is important for learning and memory [7]. The study of coordination compounds has received much attention in recent years. This interest was generated by the discovery of the anti-bacterial, -fungal and -cancer activities of several coordination compounds.

L-glutamic acid (L-H2Glu) complexes are considered an ideal form for magnesium supplementation, It is important in the metabolism of sugars and fats.

The coordination chemistry of manganese (II) has attracted considerable interest due to the crucial role played by the metal in redox and nonredox proteins. This metal ion plays an important role in the metabolism of biological systems such as superoxide dismutase [8], manganese peroxidase [9] and manganese (II) dioxygenase [10]. Emphasis has been given on the synthesis and characterisation of manganese glutamic acid complex and evaluation of its inhibition activity against some pathogens.

\section{Experimental Method}

Synthesis of Glu-Mn(II) complex: In a solution of 0.0303mmol manganese (II) chloride tetrahydrate and $0.1026 \mathrm{mmol}$ of sodium acetate trihydrate in $10 \mathrm{ml}$ water. To this solution add solution of glutamic acid $0.24 \mathrm{mmol}$. Add dropwise a solution of $0.007 \mathrm{mmol}$ of potassium permanganate in $10 \mathrm{ml}$ water with constant stirring. After the addition of the potassium permanganate solution and continue stirring for 5 minutes. Prepare a solution containing $1.570 \mathrm{~g}$ sodium acetate trihydrate in $10 \mathrm{ml}$ of water and add approximately 1-ml portion to the stirred solution. Heat the reaction mixture to near boiling (hot plate) for 10 minutes and cool to room temperature. Filter the dark solid on a small Buchner funnel and wash with water. 


\section{Result and discussion:}

The probable molecular structure of a new Manganese (II) complex with the amino acid L-Glutamic acid has been determined. From CHNS analysis the Molecular Formula for the compound was calculated as $\mathrm{Mn}\left(\mathrm{C}_{10} \mathrm{H}_{12} \mathrm{O}_{8} \mathrm{~N}_{2}\right)$. Two glutamine molecules are acting as ligands through the nitrogen atom and oxygen atom of each amino acid group, and two carboxylate oxygen atoms of two neighbouring glutamine molecules [11] the structure of $\mathrm{Mn}\left(\mathrm{C}_{5} \mathrm{H}_{6} \mathrm{O}_{4} \mathrm{~N}\right)_{2}$ was characterised with UV, IR, NMR spectroscopy and X-ray diffraction study.

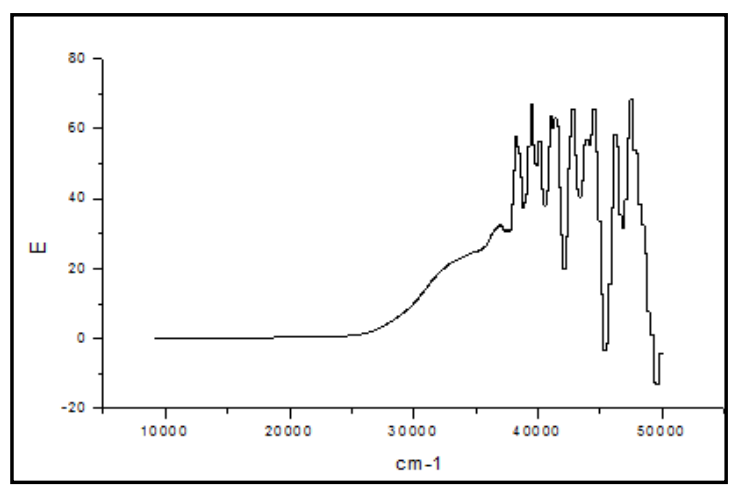

UV Spectrum

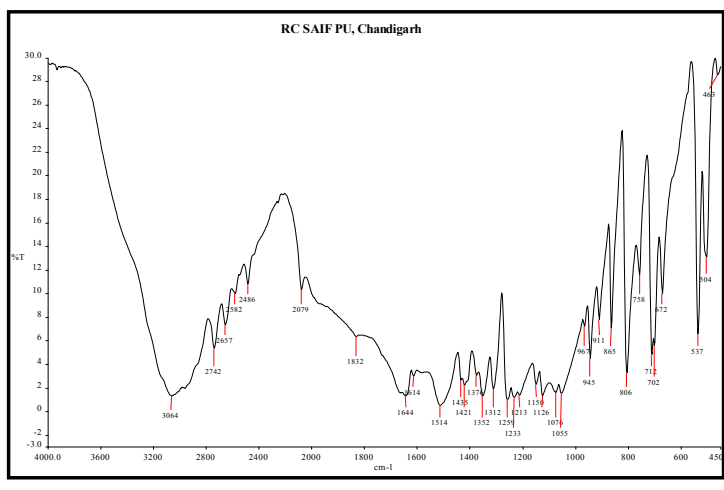

Infra-Red Spectrum

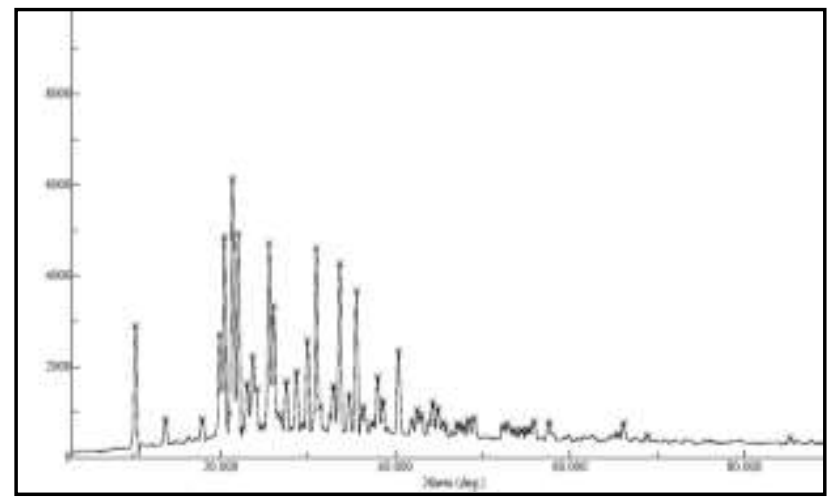

X-ray diffraction spectrum

Inhibition activity of this complex was checked against the different pathogens it was depicted in the table that zones of inhibition was observed against Candida albicans with minimum inhibition concentration $(\mathrm{MIC}=10 \mu \mathrm{l})$ for the synthesized compound. Candida 
albicans

is

a diploid fungus that

grows

both

as yeast and filamentous cells and is a causal agent of opportunistic oral and genital infections in humans [12,13] and candidalonychomycosis an infection of the nail plate.

\begin{tabular}{|c|l|c|}
\hline $\begin{array}{c}\text { Sr. } \\
\text { No. }\end{array}$ & \multicolumn{1}{|c|}{ Species } & MIC(pl) \\
\hline 1. & $\begin{array}{l}\text { Staphylococcus } \\
\text { aureus }\end{array}$ & -- \\
\hline 2. & Escherechia coli & -- \\
\hline 3. & Proteus mirabilis & -- \\
\hline 4. & Shiegella flexineri & -- \\
\hline 5. & Salmonella typhi & -- \\
\hline 6. & Salmonella paratyphi & -- \\
\hline 7. & $\begin{array}{l}\text { Klebleshiella } \\
\text { pnemoniae }\end{array}$ & -- \\
\hline 8. & Aspergillus niger & -- \\
\hline 9. & Candida albicans & 10 \\
\hline
\end{tabular}

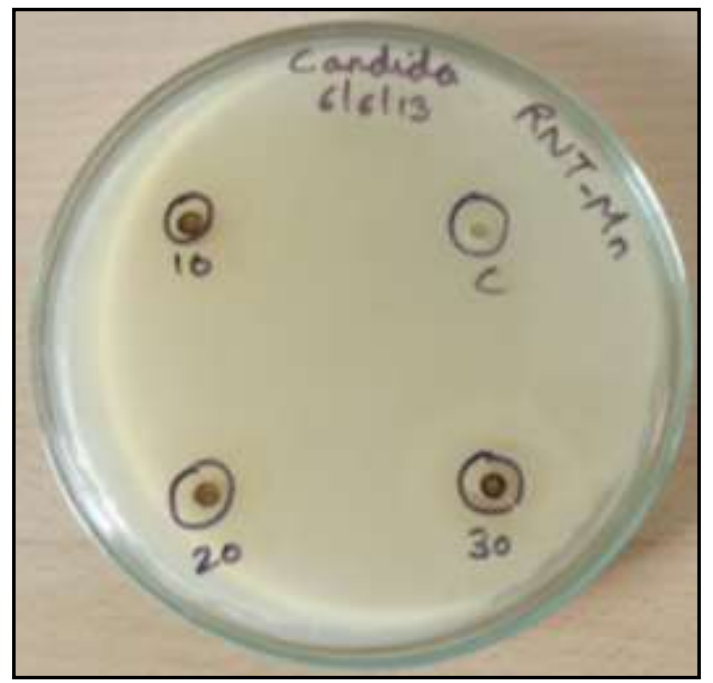

\section{Conclusion:}

The method described in this work is a simple for the synthesis of this complex. Complex is crystalline and shows inhibition activity against Candida albicans.

\section{Acknowledgement:}

MMK express gratitude to Dr. A.S. Aswar Head, Department of Chemistry, Sant Gadge Baba Amravati University, Amravati, thankful to SAIF Punjab University Chandigarh and Central Instrumentation Cell SGBAU and STIC Cochin for providing the spectral and analytical data.

\section{References:}

IUPAC-IUBMB Joint Commission on Biochemical No-menclature. Nomenclature and Symbolism for Amino Acids and Peptides. Symbols \& Terminology etc. (2007), 05, 17. 
Nelson, D.L., Cox, M.M., (2000 ). "Lehninger, principles of bio-chemistry" 3rd Edition, Worth Publishing: New York, ISBN 1-57259-153-6.

Stryer, L. (1995). Biochemistry, 4th Edition, W.H. Free-man and Company New York.

Chen, P.E., Geballe, M.T., Stansfeld, P.J., Johnston, A.R., Yuan, H., Jacob, A.L., Snyder, J.P., Traynelis, S.F. and Wyllie, D.J.A. (2005). Structural features of the glutamate binding site in recombinant NR1/NR2A N-Methyl-D- Lartate receptors determined by sitedirected mutagene-sis and molecular modeling. Molecular Pharmacology, 67, 1470-1484.

Dunn, M.S. and Smart, B.W. (1963). "DL-Lartic, Acid” Organic Syntheses, 4, 55.

Martel, A.E. (2006). Critical stability constants of metal complexes. 26.

McEntee, W. J., Crook, T. H., (1993). "Glutamate: Its role in learning, memory, and the aging brain", Psychopharmacology, 111 (4): 391401.

Bull C., Neiderhofer E. C., Yoshida T., Fee J. A., (1991). J. Am. Chem.Soc., 113, 4069.

Khindaria A., Barr D. P., Aust S. D., (1995). Biochemistry, 34, , 7773.

Whiting A. K., Boldt Y. R., Hendrich M. P., Wackett L. P., Que L., (1996). Biochemistry, 35, 160.

Schveigkardt J.M., Rizzi A.C., Piro O.E., Castellano E.E., de Santana R.C., Calvo R., Brondino C.D., (2002). Eur.J.Inorg.Chem., 2913.

Ryan K.J., Ray C.G. (2004). Sherris Medical Microbiology (4th ed.). McGraw Hill. ISBN 0-8385-8529-9.

Enfert C., Hube B., (2007). Candida: Comparative and Functional Genomics. Caister Academic Press. ISBN 978-1-904455-13-4. 